\title{
The Mediating Role of Core Competencies in the Relationship between Digital Literacy and Perceived Employability among Korean College Students: Difference by Employment Support Program Participation
}

\author{
Kyu Tae Kim \\ Department of Education, Keimyung University, Korea \\ Received March 21, 2020; Revised April 22, 2020; Accepted May 3, 2020
}

Copyright@2020 by authors, all rights reserved. Authors agree that this article remains permanently open access under the terms of the Creative Commons Attribution License 4.0 International License

\begin{abstract}
This study explored the mediating role of core competencies in the relationship between digital literacy and perceived employability among college students in South Korea depending on their participation in employment support programs. The sample for this study comprised 916 college students: 497 students were participants in employment support programs from spring to fall semesters in 2017, and 419 students were nonparticipants. Data analysis was conducted mainly using structural equation modelling and multiple-group path analysis. The findings showed that digital literacy had a positive relationship with perceived employability and that core competencies mediated the relationship between digital literacy and perceived employability. Also, this study verified that differences exist among all paths depending on participation in employment support programs. It is necessary to conduct follow-up research such as experimental and quasi-experimental research to verify the relationship and influences between related variables, as well as the effect of digital literacy and core competencies on employability according to learners' characteristics such as learning styles, learning strategies, and achievement goal orientations. Qualitative studies through group interviews or behavioral event interviews for distinguished graduates in digital literacy or core competencies are also vital. In addition, colleges need to strengthen competence-driven teaching and learning methods such as problem-based learning, flipped learning, and project-based learning. They should provide an employment-enhanced curriculum and program through digitized authentic work experience and simulation.
\end{abstract}

Keywords Digital Literacy, Core Competency,
Employability, Employment Support Programs

\section{Introduction}

Korea's youth unemployment rate is approaching 9.0\% (KRIVET, 2018). Of the newly hired college graduates, 64\% may be irregular workers and may leave their workplace within two years of employment (Lee, 2015), whereas 16\% may be "NEETs" (not being employed, educated, or trained; Oh, 2015). According to recent employment statistics in Korea, college students have a high tendency to believe that they need more time to prepare for their inadequate employment qualifications and that it is better for them while preparing for post-college employment to maintain student status rather than to graduate (Chae, 2016a, 2016b).

College students' employment problem may become worse in the era of the Fourth Industrial Revolution characterized as being hyper-connected by the Internet of Things (IoT) or being hyper-intelligent owing to big data or artificial intelligence (AI) (Schwab, 2016). The World Economic Forum (2015) maintained that the jobs of the future may be oriented toward automation, robotization, and digitization with the development of Fourth Industrial Revolution technologies. For example, the jobs of future are expected to replace unskilled laborers by introducing an AI Chatbot and a robotic system for mailing, accounting, and customer consultation. The World Economic Forum (2016) expected that $16-27 \%$ of current occupations may be replaced by data analysts, software application developers, and e-commerce experts; in 2022, 58\% of the tasks may be 
done by humans and $42 \%$ by machines or algorithms. In this regard, colleges need to improve the employability of university students by developing appropriate educational curricula, employment support programs, training courses, and programs related to the nascent Fourth Industrial Revolution technologies.

Whether college students enter current or newly emerging jobs, it is necessary to use and develop effective digital literacy as an ability to navigate and analyze data, information, and knowledge as well as to use relevant digital tools and technologies (Knight, 2011; Pirzada \& Khan, 2013; Vrana, 2016). This study explores whether the digital literacy of college students has an effect on perceived employability in future job performance and job acquisition.

Perceived employability encompasses an individual's self-perception of the likelihood of getting and maintaining a job, depending on that individual's competencies geared toward the present and future labor markets (Forrier \& Sels, 2003; Van der Heijde \& Van der Heijden, 2006; Vanhercke, De Cuyper, Peeters, \& De Witte, 2014; Wittekind, Raeder, \& Grote, 2010). If college students have core competencies coupled with sustainable employment and career success, they are more likely to be hired by future employers. Also, core competency may serve as a necessary condition for catalyzing digital literacy (Ala-Mutka, 2011; Ferrari, 2012). According to previous empirical studies, digital literacy is a kind of instrument for demonstrating core competencies such as problem-solving ability, critical thinking, communication, teamwork, and collaboration(Dabbagh \& Kinsantas, 2012; Gallarado-Eschenique, Oliveira, Marques-Molias, \& Esteve-Mon, 2015; Järvelä \& Järvenoja, 2011; Hatlevik \& Christopherson, 2013; Koltay, 2011; Lee \& Tsai, 2011). Digital literacy is improved or demonstrated through core competencies coupled with perceived employability in which perceived employability of college students may be dependent on their perception of core competencies, and digital literacy can be effectively accomplished through core competencies (De Vos, De Hauw, and Van der Heijden , 2011; Pirzada \& Kahn, 2013; Vanhercke et al., 2014; Vrana, 2016). Thus, this study examined whether core competencies play a mediating role in the impact of digital literacy on employability, filling a gap caused by a paucity of established research.

College students cultivate digital literacy, core competencies, and employability through a variety of employment support programs offered by colleges in order to prepare technologies and skills related to the Fourth Industrial Revolution. The Ministry of Education (MoE) has been implementing LINC+ (Leaders in INdustry-university Cooperation+) projects to cultivate graduates adapted to industrial needs (The Ministry of Education, 2018). Moreover, Korea's government is strengthening digital literacy programs, including learning analysis platforms and software education, so that college students can cope with the Fourth Industrial Revolution (Ministry of Science and
ICT, 2017). Korea's colleges have provided related programs such as big data, deep learning, and AI, along with career and employment support programs that focus on employability. They have also developed and implemented software-enriched curricula focusing on industrial sites, and basic software education and convergence education for non-major subjects. This trend is true of colleges worldwide. For example, England's colleges have provided their students with technology-enhanced authentic and simulated learning experiences for improving employability related with core competencies (Brammar \& Chatterton, 2014; Chatterton \& Rebbeck, 2015).In this regard, this study examines whether the influence of core competencies on the relationship between digital literacy and perceived employability depends upon student participation in employment support programs.

\section{Theoretical Backgrounds and Research Model}

Digital literacy refers to the ability to read and comprehend data and information (Bawden, 2001; Gilster, 1997) and to employ a range of digital technologies (Eshet-Alkalai \& Chajut, 2009). Martin and Grudziecki (2006) defined digital literacy as "the awareness, attitude, and ability to relevantly use digital technologies to access, manage, analyze, and evaluate digital resources, to construct new information, to create digital expression, and to communicate with others" (p. 255). Ozdamar-Kestkin, Ozata, Banar, and Royle (2015) defined digital literacy as "active participation in educational, social, and vocational life by knowing how to select and use digital technologies and information” (pp. 75-76). In this current study, digital literacy is rigorously defined as the ability to navigate, collect, analyze, and evaluate information and knowledge; to construct new information; to create digital expressions; to communicate with others; and to participate in and perform one's learning and occupations by using digital applications and technologies. Digital literacy contributes to the facilitation of perceived employability. Yen (2012) argued that perceived employability is determined by information and digital literacy. Garrido, Sullivan, and Gordon (2012) stated that developing Internet and computer skills can improve job skills and increase employability. Senior and Cubbidge (2010) maintained that the information mindset enables the promotion of employability skills.

Perceived employability is defined differently by various scholars. De Vos et al. (2011) defined perceived employability as "the continuous fulfilling, acquiring, or creating of work through the optimal use of competences" (p. 439). Vanhercke et al. (2014) defined perceived employability as "the individual's perception of his or her possibilities of obtaining and maintaining employment" (p. 594). Rothwell, Herbert, and Rothwell (2008) conceptualized perceived employability as "the perceived 
ability to attain sustainable employment appropriate to one's qualification level” (p. 2).Rothwell and Arnold (2007) refer to perceived employability as "the ability to keep the job one has or to get the job one desires” (p. 25). According to Fugate, Kinicki, and Ashforth (2004) it is conceptualized as "a form of work specific active adaptability that enables workers to identify and realize career opportunities” (p. 16). Perceived employability is associated with college students' subjective evaluation of job-related well-being and their position in the labor market (De Cuyper, Bernhard-Oettel, Bernston, Witti, \& Alarco, 2008; Forrier \& Sels, 2003; Okay-Somerville \& Scholarios, 2017; Van der Heijde \& Van der Heijen, 2006). In this study, perceived employability refers to one's belief, especially if arising from self-evaluation, about what one requires to obtain a job, maintain it, and pursue employment opportunities for new careers.

Perceived employability can be categorized into internal and external employability. Forrier, Verbruggen, and De Cuyper (2015) argued that individuals' employability is combined with the internally perceived labor market within the organization or with the present employers and to the externally evaluated labor market or with other employers. Internal employability is concerned with the self-efficacy of individuals' skills and abilities as well as with their maintenance and success in the present workplace (Rothwell, Jewell, \& Hardie, 2009). For example, internal employability includes such sentiments as "Even if there was downsizing in this organization, I am confident that I would be retained" and "Among the people who do the same as me, I am well respected in this organization" (Rothwell \& Arnold, 2007, p. 40). External employability is connected to the worker's beliefs about how easy it is to find new employment with another employer and the recent trends in the labor market (De Cuyper, Mäkikangas, Kinnunen, Mauno, \& Witte, 2012; Rothwell, Herbert, \& Rothwell, 2008); for instance, "I could easily retrain to make myself more employable elsewhere," and "If I needed to, I could easily get another job like mine in a similar organization” (Rothwell \& Arnold, 2007, p. 40).

Perceived employability is dependent on willingness to develop new competencies for the present and future labor markets (Van der Heijde \& Van der Heijden, 2006; Vanhercke et al., 2014; Wittekind et al., 2010). It was combined with core skills (Overtoom, 2000), soft skills (Finch, Hamilton, Baldwin, \& Zehner, 2013; Robles, 2012), and generic skills (Sanguinetti, 2004). Core competency is defined as the cognitive, affective, and social skills that learners need to ensure success and a competitive advantage in the present or the near future in academic and vocational life (Billing, 2007; Boyatzis, 2008, 2009; Boyatzis \& Saatcioglu, 2008; Wang, Young, Wihite, \& Marczykm, 2011). De Vos et al. (2011) maintained that perceived employability may be positively related to competency development. In this regard, perceived employability may be a variable affected by core competencies coupled with college students' sustainable employment and career success.

Core competencies may serve as a necessary condition for catalyzing digital literacy; this is because digital literacy may be recognized as a sub-variable of core competencies (OECD, 2005; K-CESA, 2017). To illustrate, OECD (2005) classified digital literacy as using tools interactively, setting a sub-variable of the following core competencies: acting autonomously and reflectively, using tools interactively, and joining and functioning in socially heterogeneous groups. In addition, MOE and Korea Research Institute for Vocational Education \& Training (KRIVET) have nationally administered the Korea Collegiate Essential Skills Assessment (K-CESA, 2019). K-CESA, like the OECD, is categorized as one of several core competency factors. This assessment evaluates communication, global mindset, human relationship, systematic thinking, resource and information use, and self-management in order to diagnose core competencies of college students and to provide appropriate career and employment guidance.

Meanwhile, it is not difficult to find that digital literacy may be dependent on core competencies such as problem-solving ability, critical thinking, communication, teamwork, and collaboration (Dabbagh \& Kinsantas, 2012; Gallarado-Eschenique et al., 2015; Järvelä \& Järvenoja, 2011; Hatlevik \& Christopherson, 2013; Koltay, 2011; Lee \& Tsai, 2011). To illustrate, Puijenbroek, Poell, Kroon, and Timmerman (2014) argue that use of social media critically and effectively may be dependent on critical thinking and cognitive skills. Janssen, Erkens, Kirschner, and Kanselaar (2009) maintain that effective online team activities are dependent upon mutual collaboration and positive critical feedback.

If digital literacy is demonstrated through core competencies as an influence upon perceived employability, will core competence mediate the influence of digital literacy on employability? This study explores whether core competencies play a mediating role in the impact of digital literacy on employability. However, the exact nature of this mediating role, assuming it does exist, and its impact in Korea is unclear because empirical studies have not examined this subject within the country. There may be a similar situation globally. There are case studies on the influence of digital literacy on employability among UK college students (Brammar \& Chatterton, 2014; Chatterton \& Rebbeck, 2015; Pirzada, \& Khan, 2013), and some empirical studies on the relationship between core competencies and employability (Finch, Hamilton, Baldwin, \& Zehner, 2013; Rao, 2014; Shah \& Srivastava, 2014). In this respect, the present study is significant in what provides empirical evidence of the mediating role of core competencies in the relationship between digital literacy and employability perceived by college students.

Korea's colleges have provided employment support programs to deal with serious youth unemployment, graduation delays, and major mismatch by changing from 
traditional learning environments to competency-based teaching and learning. South Korea's colleges have emphasized technology-enhanced curricula and programs based on big data, augmented reality (AR), virtual reality (VR), and the IoT in the era of the Fourth Industrial Revolution (Ministry of Education, 2018). The colleges provide both curriculum and extra-curricular programs. The curriculum for the Fourth Industrial Revolution is designed to provide students in either major or non-major subjects with essential or elective courses in digital literacy, software, coding, and computational thinking. Extracurricular programs related to special lectures were on the Fourth Industrial Revolution, comparative programs, big data, artificial intelligence-related intramural programs, AR / VR experiences, and so on (Kim, 2017; Kim, W., 2017; Park \& Choi, 2018). Also, colleges build digitally driven quality assurance and continuous improvement through employability data monitoring and students' learning analytics, using tools such as Moodle for conducting employment preparation activities as well as creating e-Portfolios, for feedback and reflection on the learning process, and for operating related classes and programs (Brammar \& Chatterton, 2014; Chatterton \& Rebbeck, 2015; Kilduff, Skerrett-Byrne, \& Hack, 2014). Moreover, Korean colleges have invested enormously in employment support programs for enhancing those competencies of college students that are related with employment and career development to meet the demands of the workplace environment. They have strived to increase students' employability skills by investing in employment support programs such as capstone design, on-the-job training, entrepreneurial education, employment and career counselling, and domestic and overseas company visits (Choi \& Shin, 2016; Shin, Nam, \& Min, 2013; Seo \& Kim, 2016).

Scholars are aware that employment support programs have a positive effect on perceived employability. Akkerman, Brenninkmeijer, Schaufeli, and Blonk (2015) pointed out that the CareerSkills intervention provides a chance for individuals to obtain career-related abilities such as self-efficacy, resilience, motivation, and self-managing ability. Pinto and Ramalheira (2017) argued that high academic performance related with participation in career-related extracurricular programs produced higher perceived employability. Meanwhile, Korean scholars have pointed out the pros and cons of the effects of investment in employment support programs in efforts to increase employability skills for college students who will be working in the digital work environment. Shin et al. (2013) found that employment support programs had a positive effect on college students' employment performance overall. However, they found that lower student satisfaction with the programs' operation may result in lower job performance to a greater extent than that in nonparticipating students. Chung and Kim (2013) argued that participation in employment support programs had a significant impact on employability and career preparation behaviors. Seo and Kim (2016) argued that job assistance programs do not contribute to boosting college graduates' employment and job performance. Moon, Choi, and Lim (2014) found that participation in job-seeking programs had little impact on labor market performance and employment quality.

It is necessary to revisit whether employment support programs that provide the core competencies necessary for the digital-based employment environment will also help to improve college students' perceived employability. Owing to a lack of empirical analysis, it is also necessary to explore the differences in the mediating role of core competencies in the relationship between digital literacy and perceived employability among both students who participated in the employment support programs and nonparticipating students.

This study explores whether the influence of core competencies on the relationship between digital literacy and perceived employability in college students depends upon student participation in employment support programs. The research model (see Figure 1) and hypotheses are as follows:

H1. Digital literacy has a positive influence on perceived employability.

H2. Core competencies mediate the relationship between digital literacy and perceived employability.

H3. The difference in the mediating role of core competencies on the relationship between digital literacy and perceived employability depends on students' participation or nonparticipation in employment support programs.

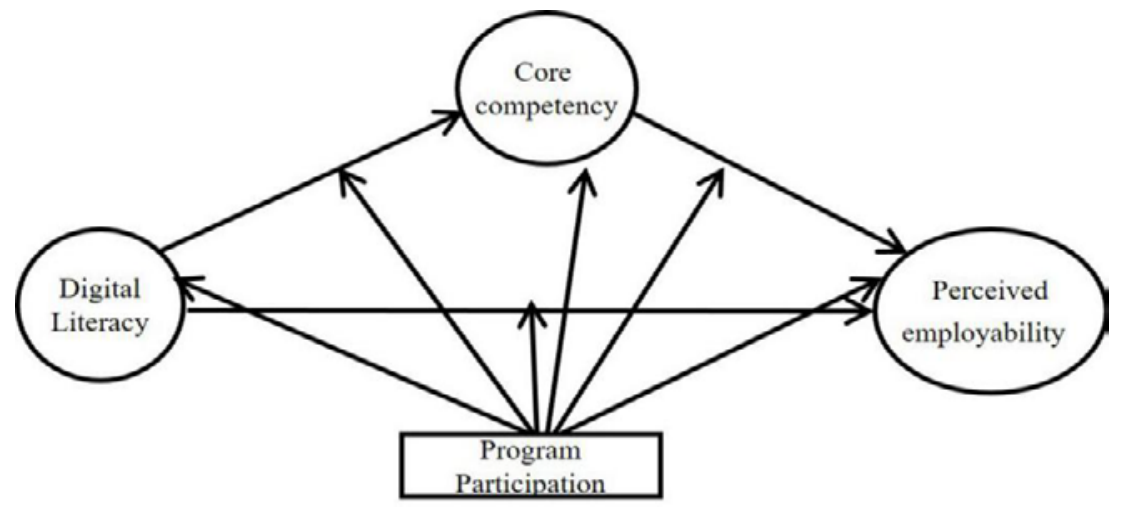

Figure 1. Research Model 


\section{Research Methods}

\subsection{Research Design}

This study employed a correlational design involving the collection of data in order to determine the degree to which a relationship exists between two or more variables and accordingly use either a research question or a hypothesis. Statistical techniques such as multiple regression analysis and structural equation modeling were designed to explore the strength and direction of the relationships between independent and dependent variables and to generate support for conceptual explanations of variable relationships. A correlational design examined the measurement variables retrospectively at a single point in time by using questionnaires consisting mainly of closed questions with a choice of fixed answers (Fraenkel, Wallen, \& Hyun, 1993; Wood \& Brink, 1998). The author investigated the mediating effect of core competencies on the relationship between digital literacy and perceived employability.

\subsection{Participant Sample}

This study applied convenience sampling in which members of the target population meet certain practical criteria, such as easy accessibility, geographical proximity, availability at a given time, or willingness to participate (Etikan, Musa, \& Alkassim, 2016; Farrokhi \& Mahmoudi-Hamidabad, 2012). The sample of this study comprised 916 voluntary participants from spring to fall semesters of 2017 from 10 universities in Seoul, Daegu, Cheongju, and Suncheon, Korea. Each college student took approximately 20 minutes to complete the questionnaires.

Table 1. Sample in this Study

\begin{tabular}{|l|l|c|c|}
\hline \multicolumn{2}{|l|}{ Participants } & N & $\%$ \\
\hline \multirow{4}{*}{ Gender } & Male & 350 & 38.2 \\
\cline { 2 - 4 } & Female & 566 & 61.8 \\
\hline \multirow{4}{*}{ Type of school } & $\begin{array}{l}\text { Humanities \& Social } \\
\text { Sciences }\end{array}$ & 389 & 42.5 \\
\cline { 2 - 4 } & Science \& Engineering & 527 & 57.5 \\
\cline { 2 - 4 } & Four-year & 526 & 57.4 \\
\cline { 2 - 4 } & Two-year & 390 & 42.6 \\
\cline { 2 - 4 } & Public & 320 & 34.9 \\
\hline \multirow{2}{*}{$\begin{array}{l}\text { Employment } \\
\text { support program }\end{array}$} & Private & 596 & 65.1 \\
\cline { 2 - 4 } & Participating & 497 & 54.3 \\
\hline Total & & 419 & 45.7 \\
\hline
\end{tabular}

The responses of the 916 participants were analyzed as the final dataset. Of these students, 350 were male (38.2\%) and 566 were female (61.8\%). The major breakdown was as follows: 389 majored in humanities and social sciences (42.5\%), and 527 were in science and engineering (57.5\%).
Furthermore, 526 were enrolled at four-year colleges (57.4\%) and 390 were enrolled at two-year colleges (42.6\%). A total of 320 were at public colleges (34.9\%) and 596 were at private colleges (65.1\%). In the spring 2017 and fall 2017 semesters, 497 students were participants (54.3\%) in employment support programs, and 419 students were nonparticipants (45.7\%).

\subsection{Measures}

The measures formulated in this study were used on the questionnaires validated in original research. It is possible that there is a limitation in assuring the accuracy and objectivity of the measurement because the measures involve the perceptions or beliefs of participants of college students about measured variables rather than objectively measured abilities related to digital literacy, core competencies, and perceived employability. The questionnaires measured in this study are as follows.

Digital literacy is an ability to use digital technologies to navigate, collect, analyze, and evaluate information and knowledge, to construct new information, create digital expression, and communicate with others for learning processes and job performance. Digital literacy was measured using an English self-report scale validated by Ozdamar-Keskin et al. (2015), designed to understand the students' abilities to use digital tools in learning. The scale was translated into Korean by the author. There are 22 items in four sub-variables: ability to use digital learning tools, managing digital learning platforms, ability to use advanced level digital tools, and security and ethics. The scales used a 5-point Likert format $(1=$ strongly disagree and $5=$ strongly agree). The items of Ozdamar-Keskin et al. (2015) and their respective Cronbach's alpha $(\alpha)$ values were ability to use digital learning tools ( $\alpha=.90,5$ items, e.g., "I can join to the events on social networks"), managing digital learning platforms ( $\alpha=.92,6$ items, e.g., "I can upload files (visual or audio) to digital platforms"), ability to use advanced level digital tools $(\alpha=.90,7$ items, e.g., "I can write a QR code and manage it"), and security and ethics ( $\alpha=.86,4$ items, e.g., "I know the digital rights of ownership").The items and Cronbach's $\alpha$ of the sub-variables in this study were ability to use digital learning tools ( $\alpha=.79$ ), managing digital learning platforms $(\alpha=.85)$, ability to use advanced level digital tools $(\alpha=.83)$, and security and ethics $(\alpha=.83)$.

Core competencies were measured with a Korean self-report instrument validated by Kim, Chung, Lee, and Yi (2010). The scale is designed to assess Korean college learners' cognitive, affective, and social skills needed to ensure success and a competitive advantage in the present or near future in their education and professional life. As shown in Table 1, there are 28 items consisting of seven sub-variables. The scales used a 5-point Likert format $(1=$ strongly disagree and $5=$ strongly agree). Cronbach's $\alpha$ for the items of Kim et al.(2010) were as follows: communication $\&$ human relationship ( $\alpha=.79,7$ items, e.g., 
“I listen and respect others' opinions”), expertise ( $\alpha=.81,4$ items, e.g., "I am able to strategically utilize expertise to fit problem situations"), creativity ( $\alpha=.81,2$ items, e.g., "I think in a variety of ways"), self-directedness ( $\alpha=.79,5$ items, e.g., "I can set my own learning goals"), general job skills $(\alpha=.81,4$ items, e.g., "I know the skills in my future career"), international mindset ( $\alpha=.76,3$ items, e.g., "I can identify global trends in your area of interest”), and problem-solving ability and thinking ( $\alpha=.76,3$ items, e.g., "I am able to derive appropriate information for problem solving"). The items and Cronbach's $\alpha$ of the sub-variables in this study were communication and human relationships ( $\alpha=.85$ ), expertise $(\alpha=.79$ ), creativity ( $\alpha=.82$ ), self-directedness $(\alpha=.86)$, general job skills $(\alpha=.77)$, international mindset $(\alpha=.74)$, and problem-solving ability and thinking ( $\alpha=.84)$.

Perceived employability refers to the belief in one's own ability to obtain a job, retain it, and enhance employment opportunities for new careers. It was assessed with sub-variables validated by Rothwell and Arnold (2007), and translated into Korean by the author. The scales used a 5-point Likert format $(1=$ strongly disagree and $5=$ strongly agree). The Cronbach's $\alpha$ and items of Rothwell and Arnold (2007) were internal employability ( $\alpha=.72,4$ items, e.g., "My personal networks will help me in my future career") and external employability ( $\alpha=.79,7$ items, e.g., "I could get any job, anywhere, so long as my skills and experience are reasonably relevant”). The items and Cronbach's $\alpha$ of the sub-variables in this study were internal employability ( $\alpha$ $=.72)$ and external employability $(\alpha=.83)$

\subsection{Data Analysis}

Data analysis for this study yielded the kurtosis and skewness to verify the normality of the data, and Cronbach's $\alpha$ to verify the reliability of the scales used in this study. A correlation analysis of the data explored the relationship between variables, and an independent sample t-test of the data enabled identification of the differences in digital literacy, core competencies, and perceived employability between groups by using SPSS 24 . This study also analyzed the mediating role in the relationship between digital literacy and perceived employability by conducting structural equation analysis and the path difference depending on program participation by conducting multiple group path analysis by using AMOS 24 .

\section{Results}

\subsection{Descriptive Statistics and Correlations}

The assessment of whether a distribution is normal or not depends on skewness and kurtosis values. According to Kline (2005), if the absolute value of kurtosis is greater than 10 and the absolute value of skew is greater than 3 , it is judged to be in violation of normal distribution. Table 2 shows that the data used in this study were found to be within the normal range of skewness $(-1.003 \sim .111)$ and kurtosis $(-.241 \sim 5.182)$ in all observed variables. Table 2 shows the results of the correlation between the variables used in this study. Overall, there was a statistically significant correlation between the observed variables at a significance level of 0.01 . The correlation analysis between the variables indicated that there was no multicollinearity, which would have indicated a highly linear relationship, among the measured values with a high correlation of 0.85 or more (Kline, 2005). 
The Mediating Role of Core Competencies in the Relationship between Digital Literacy and Perceived Employability among Korean College Students: Difference by Employment Support Program Participation

Table 2. Correlations between the Measured Variables

\begin{tabular}{|c|c|c|c|c|c|c|c|c|c|c|c|c|c|c|c|c|c|c|}
\hline \multicolumn{2}{|l|}{ Variable } & $M$ & $S D$ & Skew & kurtosis & (1) & (2) & (3) & (4) & (5) & (6) & (7) & (8) & (9) & (10) & (11) & (12) & (13) \\
\hline \multirow{4}{*}{ Digital literacy } & (1) & 3.78 & 0.72 & -.502 & .590 & 1 & & & & & & & & & & & & \\
\hline & (2) & 3.38 & 0.81 & -.099 & -.241 & $.663^{* *}$ & 1 & & & & & & & & & & & \\
\hline & (3) & 2.98 & 0.75 & .111 & .131 & $.462^{* *}$ & $.675^{* *}$ & 1 & & & & & & & & & & \\
\hline & (4) & 3.37 & 0.83 & -.221 & .038 & $.538^{* *}$ & $.616^{* *}$ & $.641^{* *}$ & 1 & & & & & & & & & \\
\hline \multirow{7}{*}{ Core competency } & (5) & 3.89 & 0.53 & -1.003 & 5.182 & $.325^{* *}$ & $.231^{* *}$ & $.150^{* *}$ & $.223^{* *}$ & 1 & & & & & & & & \\
\hline & (6) & 3.32 & 0.70 & -.298 & .662 & $.262^{* *}$ & $.305^{* *}$ & $.288^{* *}$ & $.273^{* *}$ & $.420^{* *}$ & 1 & & & & & & & \\
\hline & (7) & 3.50 & 0.78 & -.281 & .460 & $.204^{* *}$ & $.246^{* *}$ & $.220^{* *}$ & $.227^{* *}$ & $.443^{* *}$ & $.474^{* *}$ & 1 & & & & & & \\
\hline & (8) & 3.68 & 0.69 & -.568 & 1.150 & $.282^{* *}$ & $.288^{* *}$ & $.228^{* *}$ & $.288^{* *}$ & $.506^{* *}$ & $.548^{* *}$ & $.428^{* *}$ & 1 & & & & & \\
\hline & (9) & 3.44 & 0.67 & -.288 & .869 & $.257^{* *}$ & $.282^{* *}$ & $.284^{* *}$ & $.304^{* *}$ & $.455^{* *}$ & $.606^{* *}$ & $.445^{* *}$ & $.576^{* *}$ & 1 & & & & \\
\hline & (10) & 2.99 & 0.85 & -.197 & -.068 & $.219^{* *}$ & $.243^{* *}$ & $.308^{* *}$ & $.275^{* *}$ & $.282^{* *}$ & $.474^{* *}$ & $.305^{* *}$ & $.372^{* *}$ & $.418^{* *}$ & 1 & & & \\
\hline & (11) & 3.52 & 0.66 & -.194 & 1.004 & $.341^{* *}$ & $.322^{* *}$ & $.270^{* *}$ & $.345^{* *}$ & $.505^{* *}$ & $.479^{* *}$ & $.596^{* *}$ & $.558^{* *}$ & $.540^{* *}$ & $.454^{* *}$ & 1 & & \\
\hline \multirow{2}{*}{ Perceived employability } & (12) & 3.57 & 0.58 & -.027 & .554 & $.380^{* *}$ & $.276^{* *}$ & $.215^{* *}$ & $.271^{* *}$ & $.416^{* *}$ & $.410^{* *}$ & $.329^{* *}$ & $.451^{* *}$ & $.413^{* *}$ & $.235^{* *}$ & $.441^{* *}$ & 1 & \\
\hline & (13) & 3.49 & 0.63 & .050 & .285 & $.331^{* *}$ & $.234^{* *}$ & $.257^{* *}$ & $.289^{* *}$ & $.371^{* *}$ & $.409^{* *}$ & $.373^{* *}$ & $.450^{* *}$ & $.488^{* *}$ & $.315^{* *}$ & $.457^{* *}$ & $.688^{* *}$ & 1 \\
\hline
\end{tabular}

${ }^{* *} p<.01$.

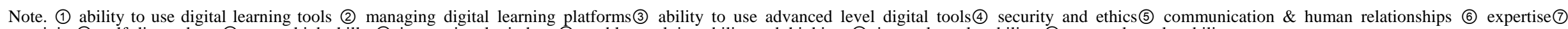
creativity (8) self-directedness (9) general job skills (1) international mindset (11) problem-solving ability and thinking (12) internal employability (1) external employability 


\subsection{Testing the Measurement Model}

The measurement model needed to confirm that the latent variables were represented by observed variables and then assess the hypothesized structural model. Several indexes were calculated to evaluate the fit of the model to the data: the chi-square $\left(\chi^{2} / d f<2.0\right.$ suggests a good fit), the comparative fit index (CFI $>0.90$ ), the Tucker-Lewis index (TLI $>0.90)$, the goodness-of-fit index (GFI $>0.90)$, the root mean square error of approximation (RMSEA $<0.10$ ), and the standardized root mean square residual (SRMR $<0.05$ ). The measurement model showed good fit statistics for the latent variables, $\chi^{2}(199)=899.945, p=0.001, \chi^{2} / d f=4.522$, $\mathrm{GFI}=0.92 \mathrm{SRMR}=0.038 \mathrm{CFI}=0.96 \mathrm{TLI}=0.94$ and RMSEA $=0.07$.

Construct validity was assessed by calculating standardized loadings and convergent validity for a measurement model. Standardized loadings are satisfactory when they are more than .05 . Convergent validity was assessed by the conceptual reliability and the Average Variance Extracted (AVE) of the factors in the measurement model. Theoretically, if the conceptual reliability is 0.7 or more and AVE is 0.5 or more, the validity of the measurement model is satisfactory (Yu, 2012). Table 3 shows that all standardized loadings of the variables were significant ( $p<0.001$; range $0.55-0.83$ for each variable). The conceptual reliability for each variable was 0.919 for digital literacy, 0.924 for core competency, and 0.915 for employability. In addition, AVE has a validity of the measurement model with digital literacy of 0.739 , core competency of 0.636 , and employment potential of 0.843 . In this regard, the construct validity of the measurement model was satisfactory.

Table 3. Convergent Validity of the Measurement Model

\begin{tabular}{|c|c|c|c|c|c|c|c|}
\hline Latent variable & $\begin{array}{l}\text { Measured } \\
\text { variable }\end{array}$ & $\begin{array}{l}\text { Unstandardized } \\
\text { coefficients }\end{array}$ & $\begin{array}{l}\text { Standardized } \\
\text { coefficients }\end{array}$ & $\begin{array}{l}\text { Standard } \\
\text { error }\end{array}$ & t value & $\begin{array}{l}\text { Construct } \\
\text { reliability }\end{array}$ & AVE \\
\hline \multirow{4}{*}{ Digital literacy } & $\begin{array}{l}\text { ability to use digital } \\
\text { learning tools }\end{array}$ & 1.000 & .779 & - & - & \multirow{4}{*}{.919} & \multirow{4}{*}{.739} \\
\hline & $\begin{array}{l}\text { managing digital } \\
\text { learning platforms }\end{array}$ & 1.208 & .834 & .050 & $23.948^{* * *}$ & & \\
\hline & $\begin{array}{c}\text { ability to use } \\
\text { advanced level digital } \\
\text { tools }\end{array}$ & 1.102 & .821 & .053 & $20.715^{* * *}$ & & \\
\hline & security and ethics & 1.102 & .742 & .051 & $21.701^{* * *}$ & & \\
\hline \multirow{7}{*}{$\begin{array}{c}\text { Core } \\
\text { competency }\end{array}$} & $\begin{array}{c}\text { communication \& } \\
\text { human relationship }\end{array}$ & 1.538 & .631 & - & - & \multirow{7}{*}{.924} & \multirow{7}{*}{.636} \\
\hline & expertise & 1.414 & .734 & .085 & $18.069^{* * *}$ & & \\
\hline & creativity & 1.561 & .606 & .091 & $15.460^{* * * *}$ & & \\
\hline & self-directedness & 1.545 & .749 & .085 & $18.340^{* * *}$ & & \\
\hline & general job skills & 1.410 & .765 & .083 & $18.624^{* * *}$ & & \\
\hline & international mindset & 1.450 & .551 & .098 & $14.376^{* * *}$ & & \\
\hline & $\begin{array}{l}\text { problem-solving } \\
\text { ability and thinking }\end{array}$ & 1.402 & .734 & .080 & $18.047^{* * *}$ & & \\
\hline \multirow{2}{*}{$\begin{array}{l}\text { Self-perceived } \\
\text { employability }\end{array}$} & internal employability & 1.000 & .811 & - & - & \multirow[b]{2}{*}{.915} & \multirow[b]{2}{*}{.843} \\
\hline & $\begin{array}{c}\text { external } \\
\text { employability }\end{array}$ & 1.128 & .742 & .053 & $21.294^{* * *}$ & & \\
\hline
\end{tabular}

${ }^{* * * *} p<.001$. 


\subsection{Testing the Structural Model}

To assess the structural model fit, the following indexes were calculated to evaluate the fit of the model to the data: chi-square $\left(\chi^{2} / d f<2.0\right.$ suggests a good fit), the comparative fit index (CFI $>0.90)$, the Tucker-Lewis index (TLI $>0.90$ ), the goodness-of-fit index (GFI $>0.90)$, the root mean square error of approximation (RMSEA < .10), and the standardized root mean square residual (SRMR <.05). The structural model showed good fit statistics for the latent variables, $\chi^{2}$ $(57)=246.946, p=0.001, \chi^{2} / d f=4.332, \mathrm{GFI}=0.96$, SRMR $=$ $0.04, \mathrm{CFI}=0.97, \mathrm{TLI}=0.95$, and RMSEA $=0.06$. All the pathways for this model were significantly positive, as is represented in Figure 2. Figure 2 shows the direct path coefficient from digital literacy to core competency was significant $(\beta=.474, p<.001)$, the direct path coefficient from digital literacy to perceived employability was significant ( $\beta=.114, p<.05)$, and the direct path coefficient from core competency to perceived employability was significant $(\beta=.655, p<.001)$.

The proportion of explained variance for the model presented by squared multiple correlations (SMC) was $22.4 \%$ for core competency and $51.3 \%$ for perceived employability
(Kline, 2005). The direct and indirect effects between pathways were presented in Table 4 . In this study, the direct effect of digital literacy on employability is .114, but the indirect effect of digital literacy on employability through core competency is .310 . This result shows that the indirect effect of core competency is greater than the direct effect of digital literacy on the employability. This result confirms that college students' perceived employability can be enhanced when core competencies play a mediating role in demonstrating digital literacy in conjunction with that perceived employability.

Bootstrapping was used to test for the significance of the mediating effect as suggested by Shrout and Bolger (2002). Bootstrapping shows the $95 \%$ confidence interval (CI) for the significance of mean indirect effect from the bootstrap results. If the CI does not include zero, the indirect effect is considered statistically significant at the 0.05 level. Table 5 shows that the results of bootstrapping analysis for the mediating effect of core competency on the relationship between digital literacy and perceived employability $(\mathrm{b}=$ 0.702, 95\% CI: $0.540 \sim 0.865$ ) were significant, because zero is not included in the range.

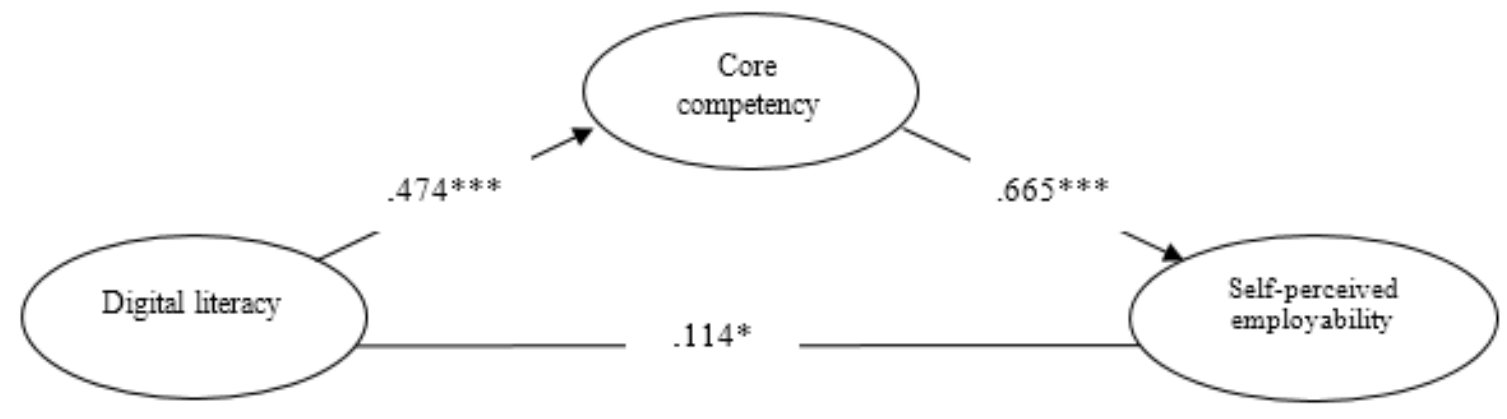

Figure 2. Standardized $\beta$ Coefficients of the Structural Model $\left({ }^{*} p<.05 .{ }^{* * *} p<.001\right)$

Table 4. Effect Decomposition of the Structural Model

\begin{tabular}{|c|c|c|c|c|}
\hline Independent variable & Dependent variable & Direct effect & Indirect effect & Total effect \\
\hline Digital literacy & Core competency & $.474)$ & - \\
\hline Digital literacy & Perceived Employability & .114 & .310 & .474 \\
\hline Core competency & Perceived Employability & .655 & .513 & .655 \\
\hline
\end{tabular}

Table 5. Bootstrapping Analysis for the Mediating Effect Test

\begin{tabular}{|c|c|c|}
\hline Pathway & $\begin{array}{c}\text { Unstandardized } \\
\text { (b) }\end{array}$ & $\begin{array}{c}\text { S.E. } \\
\text { (bias-corrected) }\end{array}$ \\
\hline Digital literacy $\rightarrow$ Core competency $\rightarrow$ Employability & .702 & .048 \\
\hline
\end{tabular}

${ }^{* *} p<.01$. 


\subsection{Group Difference Depending on Participation in an Employment Support Program}

The difference between groups by measured variables was analyzed before examining the differences in participation in the employment support program for all the paths between variables analyzed in this study. As shown in Table 6, the group differences were identified by an independent samples t-test. The mean for the participating group was higher than that for the nonparticipating group, which was statistically significant at the 0.001 level. This result implies that students who participate in employment support programs exhibit greater digital literacy, core competencies, and employability than non-participating students.

Multiple group path analysis assessed group differences by testing the structural parameters of equivalence between participants and non-participants in employment support programs, regarding whether the groups moderate the paths specified in the model (Kline, 2005). Assessing equivalence between groups involves testing sets of parameters in an increasingly restrictive manner through the hierarchical ordering of nested models, where each model constrains more parameters than the preceding model (Huh, 2013; Yu, 2012). The measurement equivalence was assessed by considering equal form, equal loadings (or measurement equivalence, $\lambda$ constraint), equal intercepts (covariance equivalence, $\Phi$ constraint), and equal residual variance (residual variance equivalence, $\Theta$ constraint). Equal loadings were tested to determine whether factor loadings are equal across groups. Equal intercepts were assessed to determine whether the regression of observed scores for each factor provided intercepts equal across groups. Equal residual variances were measured to determine whether the residual variances of the observed scores not accounted for by the factors are equal across groups. The assessment consisted of five steps (equal form $\rightarrow \lambda$ constraint $\rightarrow \Phi$ constraint $\rightarrow \lambda$ constraints, $\Phi$ constraint $\rightarrow \lambda$ constraints, $\Phi$ constraint, $\Theta$ constraint).

As shown in Table 7, multiple group confirmatory factor analysis was utilized to determine the measurement equivalence, indicating whether the constructs were being measured and were interpreted in a conceptually similar manner between the participating and nonparticipating groups. The result for Model 1 (unconstrained model) is $\chi 2$ $=337.677, d f=122$. Models 2,3 , and 4 were not statistically significant at the 0.05 significance level, and therefore the measurement equivalence of the two groups was accepted even though Model 5 was significant at the 0.05 level. It is likely to be accepted only if Models 1, 2, 3, 4 were not significant (Yu, 2012; Huh, 2013).

Table 6. Group Difference in Measured Variables

\begin{tabular}{|c|c|c|c|c|c|}
\hline \multicolumn{2}{|l|}{ Variable } & $N$ & $M$ & $S D$ & tvalue \\
\hline \multirow{2}{*}{ Digital literacy } & Nonparticipating & 419 & 3.25 & .63 & \multirow{2}{*}{$-4.020 * * *$} \\
\hline & Participating & 497 & 3.42 & .65 & \\
\hline \multirow{2}{*}{ Core competency } & Nonparticipating & 419 & 3.48 & .48 & \multirow{2}{*}{$-3.477 * * *$} \\
\hline & Participating & 497 & 3.60 & .51 & \\
\hline \multirow{2}{*}{ Perceived employability } & Nonparticipating & 419 & 3.45 & .58 & \multirow{2}{*}{$-3.512 * * *$} \\
\hline & Participating & 497 & 3.58 & .54 & \\
\hline
\end{tabular}

${ }^{* * *} p<.001$

Table 7. Multiple Group Confirmatory Factor Analysis to Determine Measurement Equivalence

\begin{tabular}{|c|c|c|c|c|c|c|c|c|c|}
\hline \multicolumn{2}{|c|}{ Model } & $\chi^{2}$ & $d f$ & GFI & CFI & RMSEA & $T L I$ & $\Delta \chi^{2}$ & Decision \\
\hline Model 1 & No constraint & 337.677 & 112 & .945 & .959 & .047 & .943 & & \\
\hline Model 2 & $\lambda$ constraint & 350.081 & 122 & .942 & .959 & .045 & .959 & $\Delta \chi^{2}(10)=12.404$ & accept \\
\hline Model 3 & $\Phi$ constraint & 347.979 & 118 & .943 & .959 & .046 & .959 & $\Delta \chi^{2}(6)=10.302$ & accept \\
\hline Model 4 & $\lambda, \Phi$ constraint & 362.408 & 128 & .941 & .958 & .045 & .958 & $\Delta \chi^{2}(16)=24.731$ & accept \\
\hline Model 5 & $\lambda, \Phi, \Theta$ constraint & 399.483 & 147 & .934 & .954 & .043 & .954 & $\Delta \chi^{2}(35)=61.806$ & rejected \\
\hline
\end{tabular}


Table 8 shows the results of verifying $\Delta \chi^{2}$, the difference of $\chi^{2}$ by analyzing the multi-group structure equation model to verify the difference in all paths among digital literacy, core competencies, and perceived employability, depending on program participation.

Table 9 shows the results of verifying the difference in $\chi^{2}$ by analyzing the multi-group structure equation model to verify the differences in all paths among digital literacy, core competencies, and perceived employability according to participation in employment support programs. After constraining each path, $\Delta \chi^{2}$ referring to the differences in $\chi^{2}$ between the two groups were analyzed. If $\Delta \chi^{2}$ is above 3.86, the path is significant at the 0.05 level, and there is a difference between the two groups. Table 7 showed that path of digital literacy to perceived employability, according to participation in employment support programs, was 3.95, significant at the 0.05 level and there is a difference between the participating and nonparticipating groups.

As shown in Table 10, for the program participation group, all paths were significant, while for the nonparticipating group, the path from digital literacy to employability was not significant in digital literacy. This result implies that college students who participate in employment support programs gain a positive effect from digital literacy on their perceived employability; moreover, it suggests that the direct effect can be higher through the mediation of core competencies. Non-participating students, on the other hand, need core competencies, as shown in the fact that the direct path was not significant and the paths mediating through core competencies are significant. This result indicates that non-participating students can improve their employability by developing core competencies in digital devices and information use.

Table 8. Model Comparison of Verifying the Path Differences According to Program Participation

\begin{tabular}{|c|c|c|c|c|c|c|c|c|c|}
\hline \multicolumn{2}{|c|}{ Model } & $\chi^{2}$ & $d f$ & GFI & CFI & RMSEA & $T L I$ & $\Delta \chi^{2}$ & Decision \\
\hline Model 1 & unconstrained & 332.896 & 112 & .946 & .960 & .046 & .945 & & \\
\hline Model 2 & $\lambda$ constraint & 345.910 & 122 & .944 & .960 & .045 & .948 & $\Delta \chi^{2}(10)=13.014$ & accept \\
\hline Model 3 & $\Phi$ constraint & 355.044 & 127 & .943 & .959 & .045 & .948 & $\Delta \chi^{2}(13)=22.148$ & accept \\
\hline Model 4 & $\lambda, \Phi$ constraint & 355.487 & 128 & .943 & .959 & .045 & .949 & $\Delta \chi^{2}(14)=22.591$ & accept \\
\hline Model 5 & $\lambda, \Phi, \Theta$ constraint & 404.457 & 148 & .934 & .954 & .044 & .951 & $\Delta \chi^{2}(34)=71.676$ & rejected \\
\hline
\end{tabular}

Table 9. Path Constraints According to Program Participation

\begin{tabular}{|l|c|c|c|c|}
\hline Path constraints & $\chi^{2}$ & $d f$ & $\Delta \chi^{2}$ & Decision \\
\hline Unconstrained & 332.896 & 112 & & \\
\hline Digital Literacy $\rightarrow$ Core Competencies & 332.983 & 113 & 0.087 & Not significant \\
\hline Digital Literacy $\rightarrow$ Perceived Employability & 336.845 & 113 & 3.949 & significant \\
\hline Core Competencies $\rightarrow$ Perceived Employability & 334.488 & 113 & 1.592 & Not significant \\
\hline
\end{tabular}

Table 10. Path Coefficient According to Participation in Employment Support Programs

\begin{tabular}{|l|c|c|c|c|}
\hline \multirow{2}{*}{ pathway } & \multicolumn{2}{|c|}{ Participants } & \multicolumn{2}{c|}{ Non-participants } \\
\cline { 2 - 5 } & $\begin{array}{c}\text { Standardized } \\
\text { coefficient }\end{array}$ & C.R. & $\begin{array}{c}\text { Standardized } \\
\text { coefficient }\end{array}$ & C.R. \\
\hline Digital Literacy $\rightarrow$ Core Competencies & .459 & $9.328^{* * *}$ & .435 & $7.861^{* * *}$ \\
\hline Digital Literacy $\rightarrow$ Perceived Employability & .216 & $4.445^{* * *}$ & .068 & 1.343 \\
\hline Core Competencies $\rightarrow$ Perceived Employability & .532 & $10.160^{* * *}$ & .681 & $10.512^{* * *}$ \\
\hline
\end{tabular}

${ }^{* * *} p<.001$ 


\section{Discussion and Conclusions}

This study examined the influence of digital literacy on perceived employability as mediated by core competencies to the extent that students participate in employment support programs.

The study found that digital literacy had a positive

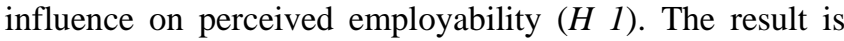
consistent with prior research showing that the use of digital technologies and information can help college students improve perceived employability in obtaining and maintaining the digitalized, robotized, and automatized future jobs (Garrido et al., 2012; Senior \& Cubbidge, 2010; Yen, 2012). This result implies that in the era of the Fourth Industrial Revolution, college students can improve their perceived employability when they are capable of effectively utilizing digital tools, technologies, and applications such as AI, IOT, robots, and software. It also suggests that appropriate communication and social participation can be enhanced through appropriate information gathering, analysis, and expression using big data and information.

This study has found that core competencies mediate the relationship between digital literacy and perceived employability (H2). This means that college students' perceived employability may be enhanced by core competencies facilitating or triggering the effective use of digital technologies and information (Ala-Mutka, 2011; Ferrari, 2012; Gallarado-Eschenique et al., 2015). Also, this is consistent with prior studies showing that critical thinking, cognitive skills, collaboration, and interpersonal relationship lead to the effective use of social media and effective performance in online team activities (Erkens, Kirschner, \& Kanselaar, 2009; Puijenbroek et al., 2014). In this respect, the significance of this study lies in the fact that it verifies the mediating role of core competencies in relation to digital literacy and perceived employability, which has not been accomplished because few empirical studies have examined this subject in Korea and elsewhere.

This study has verified that a difference exists in the mediating role of core competencies in the relationship between digital literacy and perceived employability depending on participation in employment support programs (H 3). This result implies that college students who participate in employment support can see greater direct effects through the mediation of core competencies; non-participating students, on the other hand, need to improve their employability by developing core competencies needed for using digital technologies and information use. The direct path was not significant, and the paths mediating through core competencies were significant. Also, it is significant in its verification of the empirical evidence that employment support programs provide the core competencies necessary for success in the digital-based employment environment, thereby reciprocally improving college students' perceived employability.

In conclusion, this study found both that digital literacy had a positive influence upon perceived employability and that core competencies mediated the relationship between digital literacy and perceived employability. Furthermore, this study verified that differences exist among all paths depending on participation in employment support programs

\section{Suggestions}

These results provide some implications for both future follow-up research and necessary changes in the educational practices of higher education institutions. Concerning the future follow-up research, the lack of previous research and the academic inconsistency render this study insufficient in its exploration of the effects of sub-variables of digital literacy and core competence on perceived employability, particularly with respect to the reason why core competencies facilitate digital literacy and perceived employability. Thus, it is inevitable to conduct an in-depth and logical literature review in order to delve into the influence of digital literacy on core competencies as well as to explore the differences in the definition, characteristics, and components of digital literacy and core competencies.

This study utilized a correlational research design to investigate the correlation and effect between variables through a questionnaire survey. Also, this study conducted its investigation using convenience sampling. However, there are some limitations in this study. First, only self-report measures were used. Second, only participants where a mixture of students involved in several programs were surveyed. Third, the survey was only ex-post, while predictors were assessed before the intervention. In this respect, it is not certain whether, in the context of colleges' teaching and learning, core competencies can be improved by using a variety of digital technologies in the classroom and whether the cultivated competencies were derived from lectures or support programs in colleges. It is necessary for future studies to use experimental and quasi-experimental research, that is, ex ante and ex post analysis, to verify the effects of the competence-based, technology-enhanced programs and teaching methods for enhancing perceived employability in the digital-enhanced classrooms or in a digitalized learning conditions and contexts of learners' individual learning and task performance out of their classroom.

Because of its exploration of the causal relationship, this study did not conduct group comparisons in the learners' backgrounds and characteristics. It would be necessary to investigate effect difference of the measured variables in the demographic backgrounds such as gender, major, school types (2 year/4 year), region (city/rural), the digital literacy level, and the profiles in core competency as well as to identify the effect of the learners' characteristics such as digital literacy levels, learning styles, learning strategies, self-efficacy in relation to digital literacy and perceived employability. 
There is a need to conduct qualitative studies to derive the qualitative attributes and experiences of which and how college students are using digital technologies and core competencies in the classroom and individual learning and how digital technologies are acting as learning tools and strategies to improve core competencies related with perceived employability. Additionally, it is necessary to explore the success or barrier factors through qualitative case analysis, such as focus group interviews or behavioral event interviews of distinguished graduates exhibiting high digital literacy, core competencies, and perceived employability.

As far as college education practices are concerned, this study suggests that colleges need to provide their students with competency-based, employment-enhanced curricula and programs for improving their perceived employability. The reason is that this study confirmed that self-perceived employability of college students is likely to be higher when core competencies facilitate digital literacy. Thus, colleges need to reorganize the competence-enriched curriculum in order to cultivate the creative problem-solving, communication, and creativity needed in digitalized industries and jobs of the future. Also, teaching and learning in college classrooms will need to utilize tools such as digitalized simulation, problem-based learning, flipped learning, SNS-based discussions, and robot-based programming. Furthermore, colleges not only need to provide nonparticipating students with authentic employment-enhanced scenarios and experiences using digital technologies such as holograms, virtual reality, augmented reality, and 3D printing within their classrooms but they also need to tailor competence-centered education on the basis of majors, grades, and employment fields. Additionally, a college can utilize big data to benefit its students not only by aiding in the job search and in employment preparation; it can also build digitally driven quality assurance and continuous improvement through employability data monitoring and student learning analytics. Finally, it is possible to help students to become aware of the job skills required by employers, to provide real-time feedback on resumes and self-introduction letters by using $\mathrm{AI}$ and robot programs, and to provide real interview practice by using holograms and VR.

\section{REFERENCES}

[1] Adams, C. J. (2013). 'Soft skills' seen as key element for higher Ed many teens lack crucial life skills like resiliency, grit, and the ability to communicate and advocate, and that's hurting college-completion rates. Education Digest, 78(6), 18-22.

[2] Ala-Mutka, K. (2011). Mapping digital competence: Towards a conceptual understanding. Retrieved Jan 26, 2016 from http://ftp.jrc.es/EURdoc/JRC67075_TN.pdf.

[3] Akkermans, J., Brenninkmeijer, V., Schaufeli, W. B., \& Blonk,
R. W. (2015). It's all about careerskills: Effectiveness of a career development intervention for young employees. Human Resource Management, 54(4), 533-551.

[4] Ananiadou, K., \& Claro, M. (2009). 21st century skills and competences for new millennium learner in OECD countries. Paris: OECD.

[5] Bawden, D. (2001). Information and digital literacies: a review of concepts. Journal of Documentation, 57(2), 218-259.

[6] Billing, D. (2007). Teaching for transfer of core/key skills in higher education: Cognitive skills. Higher Education, 53(4), 483-516.

[7] Boyatzis, R. E. (2008). Competencies in the 21st century. Journal of Management Development, 27, 5-12.

[8] Boyatzis, R. E. (2009). Competencies as a behavioral approach to emotional intelligence. Journal of Management Development, 28(9), 749-770.

[9] Boyatzis, R. E., \& Saatcioglu, A. (2008). A 20-year view of trying to develop emotional, social and cognitive intelligence competencies in graduate management education. Journal of Management Development, 27(1), 92-108.

[10] Brammar, L., \& Chatterton, P. (2014). Technology for employability: HE case studies (University of London). Retrieved March 5, 2018 from http://repository.jisc.ac.uk/63 61/3/UoL-case-study.pdf

[11] Chae, C. (2016a). Major matching employment analysis of college graduates. Retrieved February 25, 2018 from http://www.krivet.re.kr/ku/da/kuBDCVw.jsp?pgn=6\&gk=A LL\&gv=\&gn=G7-E520160001.

[12] Chae, C. (2016b). The reality and policy task of college students' graduation delay. KRIVET Issue Brief, 108, Retrieved February 25, 2018 from http://www.krivet.re.kr/ku $/ \mathrm{da} / \mathrm{kuBDCVw} . \mathrm{jsp}$ ?pgn=1\&gk=ALL\&gv=채창균 \&gn=G7-E 520160018

[13] Chatterton, P., \& Rebbeck, G. (2015). Technology for employability: Study into the role of technology in developing student employability. Retrieved March 5, 2018 fromhttp://repository.jisc.ac.uk/6249/3/Technology_for_emp loyability_-_full_report.PDF

[14] Choi, I. S., \& Shin, E. (2016). An empirical study of the determinants of successful job seeking of college students: Focusing on impacts of job education programs. Journal of Korean Economic Development, 23(1), 23-49.

[15] Chung, M. K., \& Kim, S. R. (2013). The mediation effect of career goal setting and career preparation behavior on relation of university's career development programs and employment. The Korea Educational Review, 19(2), 123-144.

[16] Dabbagh, N., \& Kitsantas, A. (2012). Personal Learning Environments, social media, and self-regulated learning: A natural formula for connecting formal and informal learning. The Internet and higher Education, 15(1), 3-8.

[17] De Cuyper, N., Mäkikangas, A., Kinnunen, U., Mauno, S., \& Witte, H. D. (2012). Cross - lagged associations between perceived external employability, job insecurity, and exhaustion: Testing gain and loss spirals according to the conservation of resources theory. Journal of Organizational 
Behavior, 33(6), 770-788.

[18] De Vos, A., De Hauw, S., \& Van der Heijden, B. I. (2011). Competency development and career success: The mediating role of employability. Journal of Vocational Behavior, 79(2), 438-447.

[19] Eshet-Alkalai, Y., \& Chajut, E. (2009). Changes over time in digital literacy.Cyber Psychology \& Behavior, 12(6), 713-715.

[20] Etikan, I., Musa, S. A., \& Alkassim, R. S. (2016). Comparison of convenience sampling and purposive sampling. American Journal of Theoretical and Applied Statistics, 5(1), 1-4.

[21] Farrokhi, F., \& Mahmoudi-Hamidabad, A. (2012). Rethinking convenience sampling: Defining quality criteria. Theory and Practice in Language Studies, 2(4), 784.

[22] Ferrari, A. (2012). Digital competence in practice: An analysis of frameworks. Retrieved Jan 26, 2015 from http://jiscdesign studio.pbworks.com/w/file/fetch/55823162/FinalCSReport_ PDFPARAWEB.pdf

[23] Finch, D. J., Hamilton, L. K., Baldwin, R., \& Zehner, M. (2013). An exploratory study of factors affecting undergraduate employability. Education \&Training, 55(7), 681-704.

[24] Forrier, A., \& Sels, L. (2003). The concept employability: A complex mosaic. International Journal of Human Resources Development and Management, 3(2), 102-124.

[25] Forrier, A., Verbruggen, M., \& De Cuyper, N. (2015). Integrating different notions of employability in a dynamic chain: The relationship between job transitions, movement capital and perceived employability. Journal of Vocational Behavior, 89, 56-64.

[26] Fraenkel, J. R., Wallen, N. E., \& Hyun, H. H. (1993). How to design and evaluate research in education (Vol. 7). New York: McGraw-Hill.

[27] Fugate, M., Kinicki, A. J., \& Ashforth, B. E. (2004). Employability: A psycho-social construct, its dimensions, and applications. Journal of Vocational Behavior, 65(1), 14-38.

[28] Gallarado-Echenique, E. E., de Oliveira, J. M., Marques, \& L., \& Esteve-Mon, F. (2015). Digital competence in the knowledge society. Journal of Online Learning and Teaching, 11(1), 1-16.

[29] Gardner, H. \& Davis, K. (2013). The App generation: How today's youth navigate identity, intimacy, and imagination in a digital world. New Haven, CT: Yale University Press.

[30] Garner, P. W. (2010). Emotional Competence and its influences on teaching and learning. Educational Psychology Review, 22(3), 297-321.

[31] Garrido, M., Sullivan, J., \& Gordon, A. (2012). Understanding the links between ICT skills training and employability: An analytical framework. Information Technologies \& International Development, 8(2), 17-32.

[32] Gilster (1997). Digital literacy. New York: Wiley.

[33] Hatlevik, O. E., \& Christophersen, K. A. (2013). Digital competence at the beginning of upper secondary school:
Identifying factors explaining digital inclusion. Computers \& Education, 63, 240-247.

[34] Huh, J. (2013). Easy AMOS structural equation modeling. Seoul: Hannare.

[35] Janssen, J., Erkens, G., Kirschner, P. A., \& Kanselaar, G. (2009). Influence of group member familiarity on online collaborative learning. Computers in Human Behavior, 25(1), 161-170.

[36] Järvelä, S., \& Järvenoja, H. (2011). Socially constructed self-regulated learning and motivation regulation in collaborative learning groups. Teachers College Record, 113(2), 350-374.

[37] Jones, A., \& Issroff, K. (2005). Learning technologies: Affective and social issues in computer-supported collaborative learning. Computers \& Education, 44(4), 395-408.

[38] Kilduff, S., Skerrett-Byrne, D., \& Hack, C. (2014). An open educational resource to develop digital literacy skills for employability in the life and health sciences through a staff-student partnership Retrieved March 5, 2018 from https://www.heacademy.ac.uk/knowledge-hub/open-educatio nal-resource-develop-digital-literacy-skills-employability-lif e-and

[39] Kim, S. (2017). Analysis about the initial process of learning transfer in computational thinking education. The Journal of Korean Association of Computer Education, 20(6), 61-69.

[40] Kim, W. (2017). A study on the recognition of freshman on computational thinking as essential course. Culture and Convergence, 39(6), 141-170.

[41] Kim, Y., Chung, J., Lee, C., \& Yi, Y. (2010). An analysis on undergraduate students' perception of core competencies and educational needs. Korea Educational Methodology Studies, 38(2), 59-79.

[42] Kline, R. B. (2005). Principles and practice of structural equation modeling (2nd ed.). New York: Guilford Press.

[43] Knight, S. (2011). Digital literacy can boost employability and improve student experience. Retrieved March 5, 2018 from https://www.theguardian.com/higher-education-networ k/blog/2011/dec/15/digital-literacy-employability-student-ex perience.

[44] Koltay, T. (2011). The media and the literacies: Media literacy, information literacy, digital literacy. Media, Culture \& Society, 33(2), 211-221.

[45] Korea Research Institute for Vocational Education \& Training (KRIVET) (2018). Human resources development indicators in Korea. Retrieved August 3, 2018 from http://www.krivet.r e.kr/ku/da/kuBBAVw.jsp?gn=E1-E120183266.

[46] KRIVET (2019). Korea Collegiate Essential Skills Assessment. Retrieved May 16, 2019 from https://www.kces a.re.kr/index.do

[47] Lee, E. (2015). The relationship among satisfaction of college education, major-job matching, work utilization and wages of major knowledge. Retrieved March 5, 2018 fromhttp://www .krivet.re.kr/ku/da/kuBDCVw.jsp?pgn=7\&gk=ALL\&gv=\&g $\mathrm{n}=\mathrm{G} 7-\mathrm{E} 520150016$

[48] Lee, S. W. Y., \& Tsai, C. C. (2011). Students’ perceptions of 
collaboration, self-regulated learning, and information seeking in the context of Internet-based learning and traditional learning. Computers in Human Behavior, 27(2), 905-914.

[49] Martin, A., \& Grudziecki, J. (2006). DigEuLit: concepts and tools for digitalliteracy development. Innovation in Teaching and Learning in Information and Computer Sciences, 5(4), 249-267.

[50] Ministry of Science and ICT (2017). Sharing and spreading university software education innovation model. http://www.msit.go.kr/web/msipContents/contentsView.do?c ateId=mssw315\&artId=1323719

[51] Moon, S., Choi, K., \& Lim, S. (2014). Influence of college career support on helping market and its results. Journal of Korean HRD Research, 9(2), 27-50.

[52] Organization for Economic Cooperation Development (2005). The definition and selection of key competencies. Retrieved May 16, 2019 from https://www.oecd.org/pisa/35070367.pdf

[53] Oh, H. (2015). The situation and task of Kangaroo youth. Retrieved March, 2, 2019 from http://www.krivet.re.kr/ku/da /kuBDCVw.jsp?pgn=7\&gk=ALL\&gv=\&gn=G7-E52015001

[54] Okay-Somerville, B., \& Scholarios, D. (2017). Position, possession or process? Understanding objective and subjective employability during university-to-work transitions. Studies in Higher Education, 42(7), 1275-1291.

[55] Ozdamar-Keskin, N., Ozata, F. Z., Banar, K., \& Royle, K. (2015). Examining digital literacy competences and learning habits of open and distance learners. Contemporary Educational Technology, 6(1), 74-90.

[56] Park, G., \& Choi, Y. (2018). Exploratory study on the direction of software education for the non-major undergraduate students”, Journal of Education \& Culture, 24(4), 273-292.

[57] Pink, D. (2006). A whole new mind: Why right-brainers will rule the future. New York: Riverhead Books.

[58] Pinto, L. H., \& Ramalheira, D. C. (2017). Perceived employability of business graduates: The effect of academic performance and extracurricular activities. Journal of Vocational Behavior, 99, 165-178.

[59] Pirzada, K., \& Khan, F. N. (2013). Measuring relationship between digital skills and employability. European Journal of Business and Management, 5(24), 124-133.

[60] Puijenbroek, T., Poell, R. F., Kroon, B, \& Timmerman, V. (2014). The effect of social media use on work-related learning. Journal of Computer Assisted Learning, 30, 159172.

[61] Rao, M. S. (2014). Enhancing employability in engineering and management students through soft skills. Industrial and Commercial Training, 46(1), 42-48.

[62] Robles, M. M. (2012). Executive perceptions of the top 10 soft skills needed in today's workplace. Business Communication Quarterly, 75(4), 453-465.

[63] Rothwell, A., \& Arnold, J. (2007). Self-perceived employability: development and validation of a scale. Personnel Review, 36(1), 23-41.

[64] Rothwell, A., Herbert, I., \& Rothwell, F. (2008).
Self-perceived employability: Construction and initial validation of a scale for university students. Journal of Vocational Behavior, 73(1), 1-12.

[65] Rothwell, A., Jewell, S., \& Hardie, M. (2009). Self-perceived employability: Investigating the responses of post-graduate students. Journal of Vocational Behavior, 75(2), 152-161.

[66] Schwab, K. (2016). The fourth industrial revolution. Geneva, Switzerland: World Economic Forum.

[67] Senior, C. \& Cubbidge. (2010). Enhancing employability in the ME generation. Education+Training, 52(6/7), 445-449.

[68] Seo, H. \& Kim, B. (2016). Analysis on structural relation among employment supporting program, university educational satisfaction, job satisfaction and job match. Korean Journal of Educational Administration, 34(3), 51-75.

[69] Shah, R. J., \& Srivastava, N. (2014). A study on factors affecting employability skills of management students. International Journal of Management and Development Studies, 3(2), 17-24.

[70] Shin, H. S., Nam, S., \& Min, B. C. (2013). Evaluating the effectiveness of universities' employment support programs on employment status. The Journal of Economics and Finance of Education, 22(1), 211-235.

[71] Shrout, P. E., \& Bolger, N. (2002). Mediation in experimental and nonexperimental studies: New procedures and recommendations. Psychological Methods, 7, 422- 445.

[72] Solomon, G., \& Schrum, L. (2007). Web 2.0: New tools, new schools. Eugene, OR: International Society for Technology in Education.

[73] The Ministry of Education (2018). Leading innovative university to the Fourth Industrial Revolution. Retrieved March 5, 2018 from http://www.moe.go.kr/boardCnts/view.d o ?boardID=294\&boardSeq=73088\&lev=0\&searchType=null \&status $\mathrm{YN}=\mathrm{C} \&$ page $=8 \& \mathrm{~s}=$ moe $\& \mathrm{~m}=0503 \&$ opType $=\mathrm{N}$

[74] Van Der Heijde, C. M., \& Van Der Heijden, B. I. (2006). A competence - based and multidimensional operationalization and measurement of employability. Human Resource Management: Published in Cooperation with the School of Business Administration, The University of Michigan and in alliance with the Society of Human Resources Management, 45(3), 449-476.

[75] Vanhercke, D., De Cuyper, N., Peeters, E., \& De Witte, H. (2014). Defining perceived employability: a psychological approach. Personnel Review, 43(4), 592-605.

[76] Vrana, R. (2016). Digital literacy as a boost factor in employability of students. In European Conference on Information Literacy (pp. 169-178). Springer, Cham.

[77] Wang, N., Young, T., Wihite, S. C., \& Marczykm G. (2011). Assessing students' emotional competence in higher education: Development and validation of the Widener Emotional Learning Scale. Journal of Psychoeducational Assessment, 29(1), 47-62.

[78] Wittekind, A., Raeder, S., \& Grote, G. (2010). A longitudinal study of determinants of perceived employability. Journal of Organizational Behavior, 31(4), 566-586.

[79] Wood, M. J., \& Brink, P. J. (1998). Correlational designs. Advanced design in nursing research (2nd ed.). Thousand 
Oaks, CA: Sage Publications.

[80] World Economic Forum. (2016). The future of jobs. Retrieved May 5, 2019 from http://www3.weforum.org/docs/ WEF_Future_of_Jobs.pdf

[81] World Economic Forum (2015). Deep shift technology tipping points and societal impact.Retrieved May 5, 2019 from http://www3.weforum.org/docs/WEF_GAC15_Technologica 1_Tipping_Points_report_2015.pdf.

[82] Yang, J. (2017). University life change of 4-year college students over the past 10 years. KRIVET Issue Brief, 125, Retrieved February 25, 2018 from http://www.krivet.re.kr/ku /da/kuBDCVw.jsp?pgn=1\&gk=ALL\&gv=양정승\&gn=G7G720170014.

[83] Yen, M. (2012). Construction and empirical analysis of the indicators of college students' basic information ability for employability. Knowledge Management \& E-Learning: An International Journal (KM\&EL), 4(3), 379-389.

[84] Yu, J. P. (2012). Concepts and understanding of structural equation modeling. Seoul: Hannare. 